\title{
THE IDENTITY AND WORSHIP OF HUMAIN REMAINS \\ IN ROCKSHELTER SHRINES AMONG THE NORTHERN LACANDONS OF MENSABÄK
}

\author{
AndREa CuCINA \\ VERA TIESLER \\ Facultad de Ciencias Antropológicas, \\ Universidad Autónoma de Yucatán \\ Joel PalKa \\ Department of Anthropology, \\ University of Illinois
}

\begin{abstract}
The present bioarchaeological and taphonomic investigation focuses on the skeletal remains deposited on surfaces of Lacandon rock-shelter sanctuaries around the Mensabäk lagoon in Chiapas (in particular the ones of Sak Tak and Mensabäk). The Lacandon locals still identify these remains with their ancestors and deities. Here we examine the minimum number of individuals, the age-at-death and sex profiles of those who comprise the assemblages, and their skeletal indications of physiological stress, trauma and cultural modification. Equally distributed between males and females, the series are made up of mainly middle-age adults, with subadults noticeably missing. Al preserved skulls express the effects of cradleboard use (tabular erect form). The pathological conditions recorded in this study appear as criba orbitalia and porotic hyperostosis in the skull, and periostal reactions in the long bones; however, the secondary nature of the deposit limits the possibility of making specific diagnoses.
\end{abstract}

KeYwords: Bioarchaeology, human taphonomy, Maya rock-shelter sanctuaries, Lacandons, Chiapas.

RESUMEN: El trabajo resume la investigación bioarqueológica y tafonómica de restos humanos esqueletizados en las superficies de los santuarios de abrigos rocosos que rodean la laguna de Mensabäk, Chiapas (con especial atención a los abrigos de Sak Tat y Mensabäk), lugares todavía considerados santuarios por los lacandones, quienes identifican las osamentas como antepasados y deidades.

En el estudio se examinan el número mínimo de individuos en cada contexto, los datos biovitales (sexo y edad), algunos marcadores de estrés fisiológico y de trauma, así como las modificaciones culturales en los restos que integran los contextos. La evidencia ósea indica una proporción general equitativa entre hombres y mujeres adultos, cuyas edades se centran en la edad media. No aparecen representados individuos infantiles. Todos los cráneos evaluables presentan modificaciones artificiales en su morfología, efectuadas en cuna. La evidencia patológica analizada se manifiesta en forma de criba orbitalia e hiperostosis porótica en los cráneos, y reacciones 
periostales en los huesos largos, aunque el origen secundario de los depósitos limita un diagnóstico preciso. Marcas antrópicas halladas en algunos segmentos hablan de violencia peri mortem y posibles procesamientos póstumos de los cuerpos.

Palabras clave: bioarqueología, tafonomía humana, santuarios mayas de abrigo, lacandones, Chiapas.

RECEPCIÓN: 25 de noviembre de 2013.

ACEPTACIÓN: 11 de febrero de 2014. 


\title{
THE IDENTITY AND WORSHIP OF HUMAIN REMAINS IN ROCKSHELTER SHRINES AMONG THE NORTHERN LACANDONS OF MENSABÄK
}

\author{
Andrea CuCina \\ VERA TIESLER \\ Facultad de Ciencias Antropológicas, \\ Universidad Autónoma de Yucatán \\ JoEL PALKA \\ Department of Anthropology, \\ University of Illinois, Chicago
}

\section{Introduction}

Rock-shelters, caves, cenotes and crevices are considered sacred places in Maya thought and cosmology, in particular as providing access to the sacred mountain, the Maya cosmic womb. Given the primordial role that such places play in Mesoamerican cosmos, it is not difficult to understand how mortal remains of Maya ancestors, in the form of single skeletal segments (skulls, long bones), or complete lifeless human bodies, appear prominently in rituals performed in these hidden natural geological formations (Blom, 1954; Brady and Prufer, 2005; Cucina and Tiesler, 2014). Specifically these rituals that involved the human body could have been motivated by ancestral veneration, sacrifice or simple funerary disposal. Performed either in private or in the public domain, their enactment was most certainly diverse across the Maya cultural landscape over time.

It follows from the above that the understanding of Maya scatology and linked to caves and rock-shelters benefits from the insights gained form the examination of human remains from subterranean passages (Bassie-Sweet, 1996; Bonor Villarejo, 1989; Brady and Prufer, 2005; Stone, 1995). Nonetheless, despite their importance, the investigation of skeletonized human remains in Maya subterranean contexts by itself represents a field of study that is still in the process of growth and formalization (Scott and Brady, 2005; Tiesler, 2005). At present, our knowledge of the forms of deposition, disposal and post-depositional treatments remains fragmentary and our understanding of circumstances, cultural, and chronological relationships is still limited.

The present paper focuses on the taphonomic (both cultural and natural) and bioarchaeological analysis of human skeletal remains encountered in a number 
of crevices and rock-shelters around de Mensabäk lagoon in Chiapas (México), and collectively dated to the Postclassic period and the post-conquest era (figures 1 and 2). Given the sacred roles of rockshelters and crevices in the native Maya worldview, we wonder specifically about the timing, the circumstances, and the meanings of placing deceased individuals or their skeletal segments in the rock sanctuaries documented around the lake on Mensabäk. Did these individuals represent specific segments of their group, i.e. those who were entitled to represent the living before the gods? Or was there a more homogeneous distribution in terms of sex and age categories that might mirrors a normal mortality distribution and imply that the shelters had been originally used as funerary depositories for all? The parallelisms or differences in the exploitations of these passages in comparison with caves in the Chiapanec region as well as with other Maya localities likely shed light on the way crevices and rock-shelters were used for mortuary purposes in the Lacandon Maya area, and to provide glimpses of the motivations and circumstances.

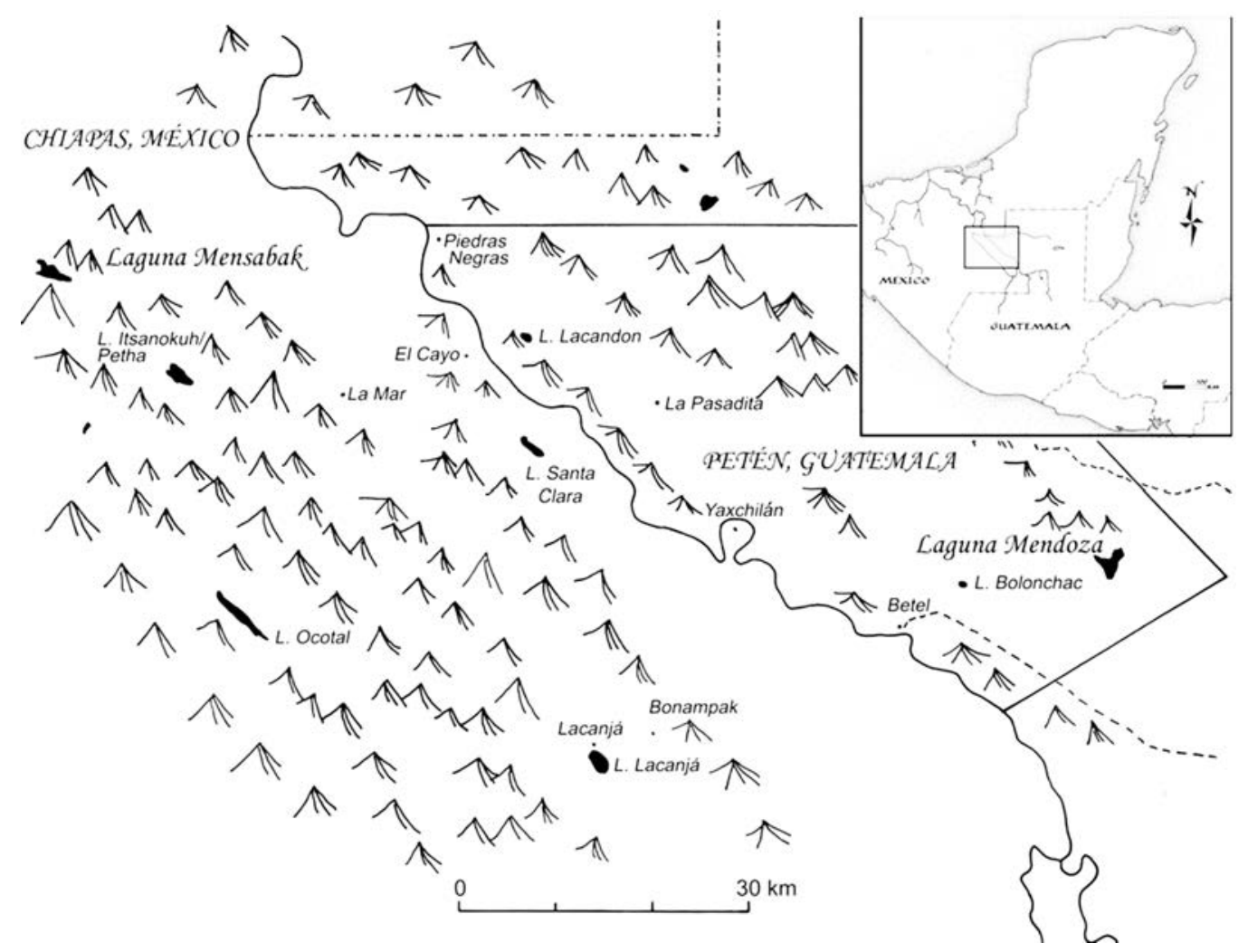

Figure 1. Regional map of the Lacandon area in Chiapas 

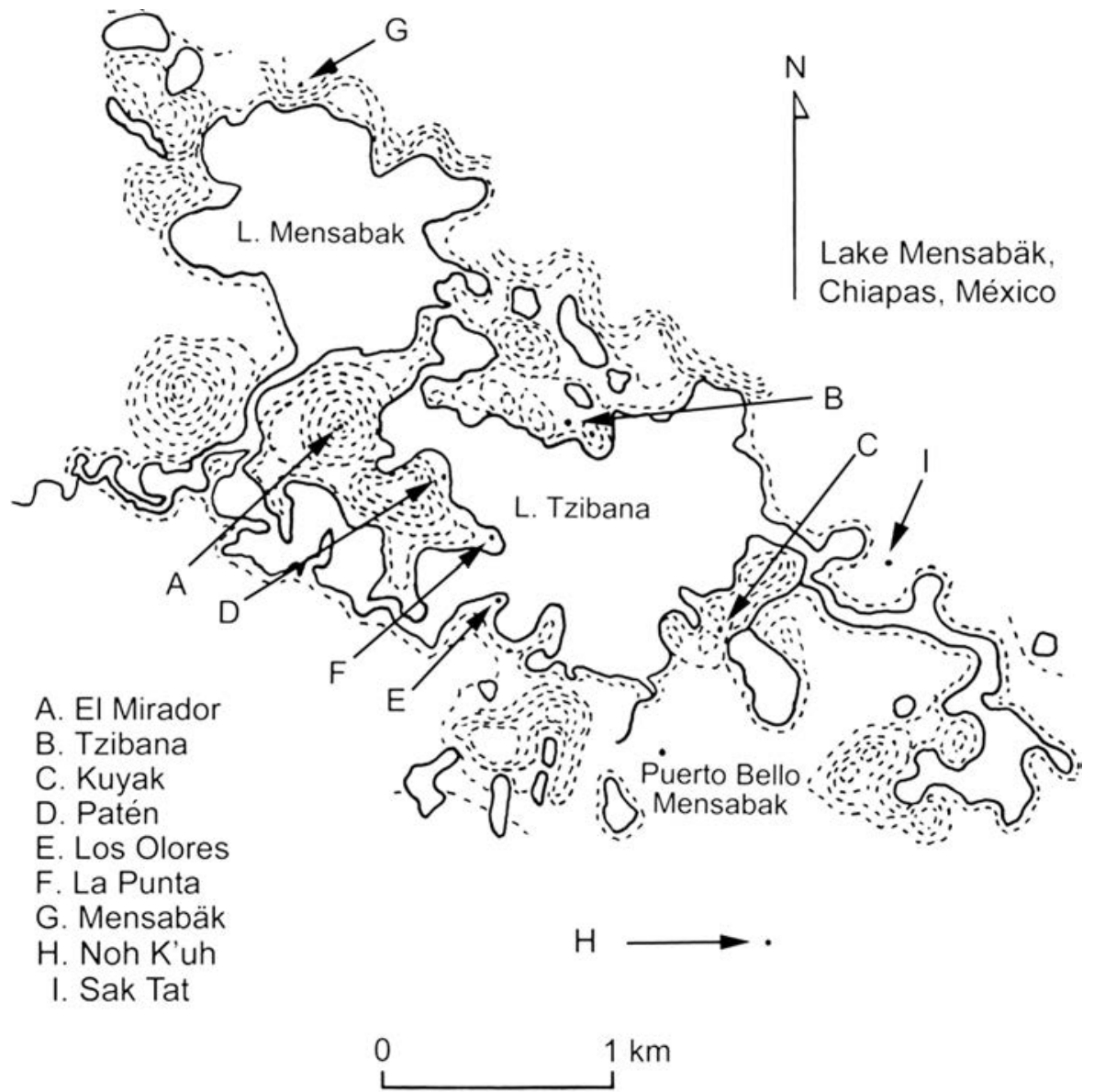

FIGURE 2. Location of the main shrines around the Mensabäk lagoon

The human assemblages from shores of the Mensabäk lake

The lagoons that stretch over the Mensabäk lake area are embedded in the Lacandon Sierra, located in the modern state of Chiapas (México) (figures 1 and 2). Since the dramatic changes that accompanied the so-called Maya "collapse" at the close of the first millennium A.D., the lands surrounding its shores have remained covered by dense subtropical forest. Over the centuries, these stretches have seen territorial shifts and isolation, remaining sparsely populated by Maya groups, for the most part consisting of small hamlets or camp sites (Palka, 2005; Palka and Sánchez, n. d.) (figures 1 and 2).

Since pre-Hispanic times, the lake has represented a valuable and rich source of water and food for all the human groups that settlers around, or in close proxi- 
mity to its shores. Recent surface analyses and explorations highlighted the presence of archaeological structures dated to Late Preclassic times and then to the Late Postclassic to colonial period transition (Palka and Sánchez, n. d.). Given the geological features of the region, the lagoon is surrounded by a considerable number of rock-shelters, crevices and caves; because of the ritual importance in indigenous culture, they have long been the objects of and place for rituals (Boremanse, 1993; Petryshin, 2005).

Northern Lacandon folk have traditionally held that the rain god Mensabäk himself inhabited the shores of this lagoon, while Tsíbatnah, Mensabäk's younger brother, was the owner of a shrine on the Tzibana lagoon. Another humanlike natural force, K'ka', was held to reside together with his son-in-law K'in Bor, in two different shelters in a cliff towards the small K'ak' lagoon to the southeast of the two big lagoons (Boremanse, 1998: 158; figure 2).

Until recently, Lacandon Maya have performed religious ceremonies and made offerings on a regular basis in these and other nearby rock passages. These rituals are still recalled by today's community members and are also documented by the abundant presence of ritual ceramic vessels (so called "god pots"). Most of these vessels still contain copal. The walls of these shelters still appear blackened from soot; in many of them, human skeletal assemblages are stacked on the ground. A large number of human skeletal remains have been accumulating over time, or beneath, the surface of these shelters, the majority corresponding to isolated bones. A number of authors, like Didier Boremanse, John McGee, or Gertrude Blom, hold that the human remains from the Mensabäk lake shelters that now form part of the cave rituals, must have come to the surface when the burial inside the cave substarte were looted (Boremanse, 1993; Petryshin, 2005).

The osteological and taphonomic analyses at Mensabääk were carried out during 2010 and 2011 and encompassed several sacred contexts ranging from minor, isolated shelters with few skeletal and ceramic fragments, to large ritual deposits characterized by an abundance of Lacandon Maya "god-vessels" (shiicas) and human remains. Given such variability, we will focus this study on the Mensabäk and Sak Tat rock-shelters that are the most important sacred shrines around the lagoon and those that contain the great majority of human remains.

The Mensabäk rock-shelter is located long the northwestern shores of the lagoon (identified by letter $G$ in figure 2). Its distance from the shore depends on the water level, ranging from about two to ten meters. Copious amounts of ceramic vessels and skeletal remains form an anthropogenic, deposit spanning an area of some ten $\mathrm{m}^{2}$ (figure $3 \mathrm{a}$ and b). Some fifty meters way from this deposit, an elevated crevice contains skeletal and cranial segments together with two complete, partially mummified primary individuals.

The second sacred shrine, to be examined in details, is the rock-shelter of Sak Tat (identified by letter I in figure 2, figure $4 a$ ). It is formed geologically by a crevice and a large overhanging rock, protecting an area of approximately fifteen meters of width by eight meters (figure $4 \mathrm{~b}$ ). This feature lies along a meandering 

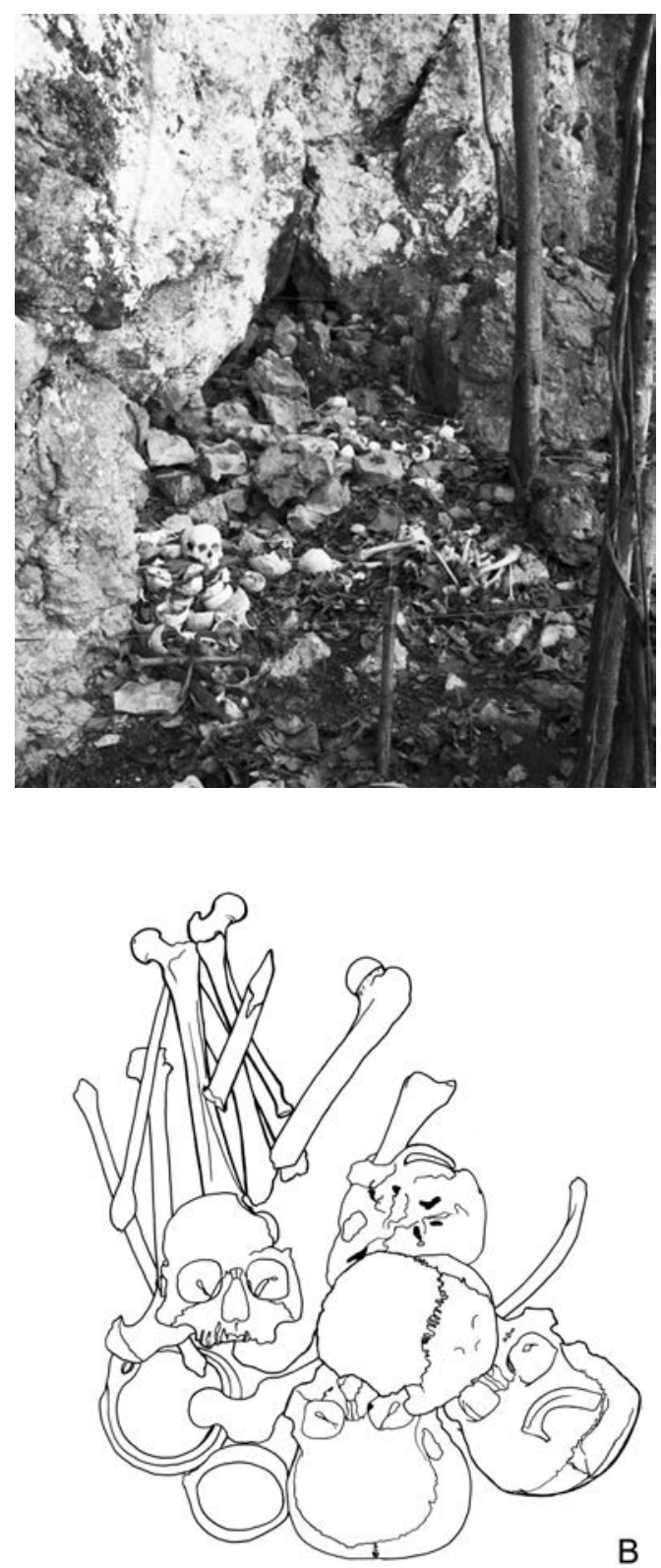

FiguRE 3. (a) General view of the Mensabäk rock-shelter (b) drawing, of main concentration of human bones, which are regularly moved within the shrine during visits (drawing by M. Sánchez) 
branch of the Sak Tat lagoon to the southwest of the larger lagoons. It is hidden by dense vegetation. Besides being the largest ceremonial deposit at the lagoon, Sak Tat is also the shrine that hosts the largest number of skeletal remains that were spread across its surface. The many aligned Lacandon "god-vessels" along the shelter's northeastern wall, and the distribution of skeletal remains on the surface, and immediately underneath it, document the extensive use of the shrine as mortuary deposit and as a place of ritual offerings. Human remains also filled the minor crevices at the bottom of the rocky walls of the Sak Tat shrine; these crevices are so narrow that the remains could not be studied systematically.
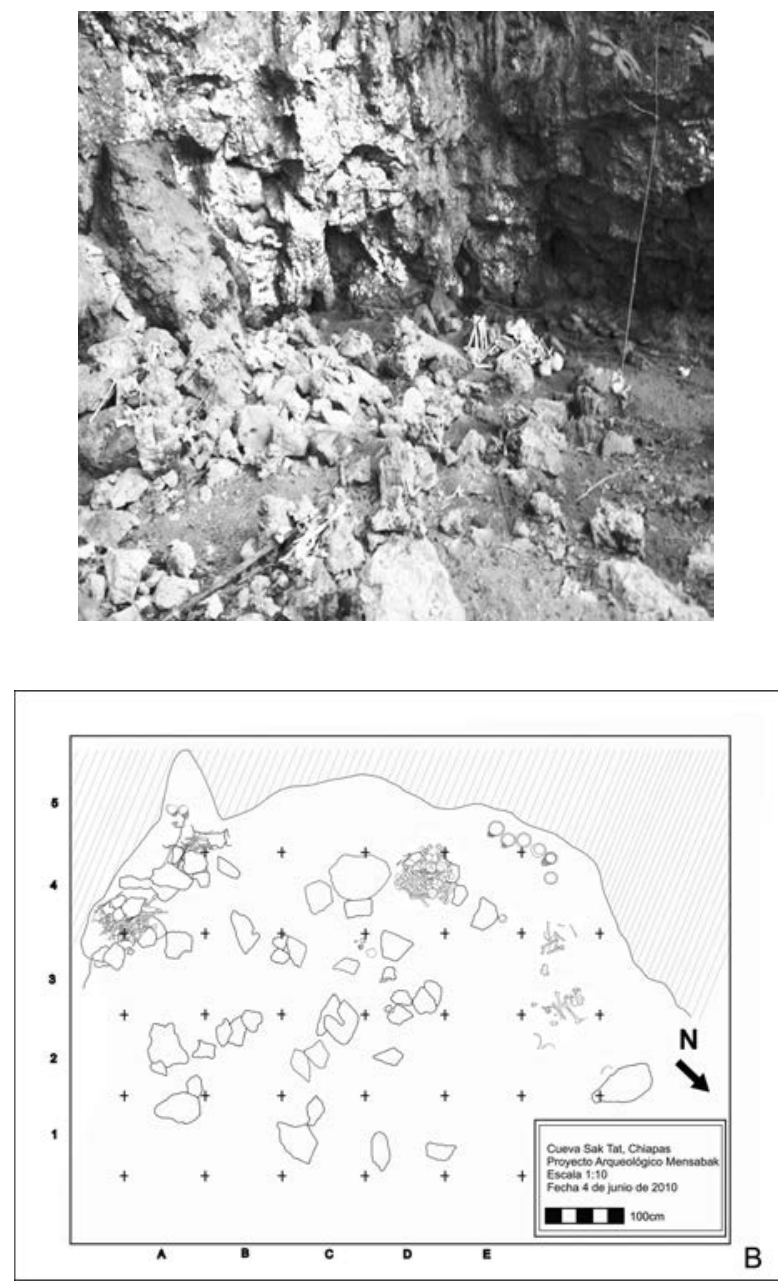

FIGURE 4. (a) Bone accumulation at the Sak Tat rock-shelter (b) drawing, indicating dimensions and surface features (ceramic incense burners and human assemblages (drawing by M. Sánchez) 


\section{Materials and methods}

Our skeletal analyses centered on the macroscopic surface inspection and metric measurements of the most significant skeletal segments, recovered from six rock shelters, with particular emphasis on the series from Sak Tat and Mensabäk. Because the skeletal assemblages on the surface consisted of secondary remains, analyses of single individuals could not be performed, at least during surface screening. Instead, significant anatomical segments like skulls, mandibles, iliac bones, femurs, tibias and humeri were scored separately and used as parallel sources of information.

Surface re-collection procedures. During the field season in 2010, a $2.0 \times 2.0$ meters grid was laid out in each of the two contexts, covering the shrines' surface documentation started. Because of the sacred nature of the shrine, and complementary beliefs on male and female gender roles, only male members of the team were allowed into the shrines. The latter were accompanied by at least one Lacandon community member, who also guided the work group to the sites each day. Following the anthropologists' instructions, the Lacandon guide collected all specimens systematically and one at a time after putting on latex gloves. Each bone was identified in a sketch and was passed on for onsite anthropological inspection on the verge of the rock-shelter, which was carried out in an improvised working station. With no permit for collection (the anthropological intervention was only intended as a surface screening), and given the Lacandons' concern about their sacred shrines and the remains of their ancestors (the shrines are still in use for sacred rituals), each specimen was returned right after scoring to the exact place where it had been recovered.

Test pitting. During subsequent field seasons in 2011 and 2013, and once permission had been granted, one test pit was excavated in each of the two large rock-shelters under study in order to assess the stratigraphy and depth of the substrate and to document potential primary deposits and patterns of disturbance. As these studies have not yet been concluded, we will only refer here to one C14 date, obtained by Accelerator Mass Spectrometry (AMS) from a sample extracted in the bottom substrate of the test pit from Sak Tat.

Taphonomic assessment. For both assemblages, we obtained information on the minimum number of individuals (MNI), along with the state of articulation and secondary vs primary burial status (Adams and Koningsberg, 2008; Duday, 2009). Unfortunately, the probable number of individuals (PNI) could not be determined due to the onsite recording strategies. The presence of anthropogenic marks in the form of perimortem fractures, slicing or chop marks, were examined on all uneroded surfaces. 
Skeletal assessment. Age at death was estimated separately for each segment. For the skulls, the obliteration of cranial sutures was considered based on Buikstra and Ubelaker (1994). Given the secondary nature of the assemblages, the number of teeth was very small, due to normal post-mortem fall from the sockets. There for, dental wear was not implicated as an indicator of biological age of the skull or mandible. Also the presence of degenerative processes in the skulls, which could help assign an age range, was used as one more general indicator of biological age.

The pubic symphyses and the auricular surfaces of the iliac bones were scored to estimate age at death, following Suchey, Todd and Lovejoy and colleagues (Buikstra and Ubelaker, 1994; table 1). Sex determination rested on the morphological dimorphism of the pelvis and the evidence of sexually dimorphic traits in the skull (Ferembach et al., 1980; Steele and Bramblet, 1988; Buikstra and Ubelaker, 1994; Bruzek, 2002; Sánchez-Mejorada et al., 2011). Long bones were sexed based on the degree of robusticity, following the discriminant functions by Wrobel et al. (2002). Long bones were also measured to estimate stature in the living individuals. Maximum length was recorded in femurs and tibias and stature was estimated based on the regression formulas by Del Ángel and Cisneros (2004).

Stress markers and traumatic conditions were diagnosed macroscopically onsite in all preserved cranial and postcranial segments. Osteomielitis and periostitis were recorded in the postcranium, criba orbitalia and porotic periostosis as markers of metabolic childhood stress, and traumas as indicators of violence, following general criteria as described in Ortner (2003). It must be underscored that dental and oral pathologies were also recorded during the analysis; nonetheless, the reduced number of dental and alveolar segments limits any possible interpretation and therefore are not employed in the present study.

Lastly, cultural head shaping was morphologically and morphometrically recorded according to type, variant, degree of expression and secondary alterations, like suprainion lesions, following Dembo and Imbelloni (1938), Romano (1965) and Tiesler $(1999,2012,2014)$. The assigned taxonomies were compared to the distribution of cultural head forms according to area an era. Additionally, cultural dental modifications were documented when present.

\section{Results}

Dating the human deposits. An Accelerator Mass Spectrometry (AMS) dating of two samples of human bone form the lowest level of the test pit at Sak Tak, excavated in 2011, indicate a date between 1460 and 1650 of the current era. These dates suggest human occupation during the Late Postclassic or Colonial period. With these results, we do not know about the whole span of more recent activity, naturally, a shortcoming due to the problems with C14 calibration in the period beyond the $16^{\text {th }}$ century AD. For now, the examination based on type-variety of a 
few ceramic sherds found on the surface of the shrine confirms these dates, as do the uniformly broad and short silhouettes of the documented skulls. These stand out against the diversity of head dorms expected for Classic period populations from this area, while characterizing the techniques during the second millennium of our era (Tiesler, 2012; 2014). In the case of the Lacandon, their flattened foreheads are described by Maudslay as still occurring during the late $19^{\text {th }}$ century, as we will describe further in this paper.

Disposition, state of articulation and preservation of individuals. The taphonomic analysis of the surface deposits indicated that almost all the human skeletal remains, either partly interred or fully exposed on the surface, were secondary depositions. Only two partly mummified bodies in the Mensabäk shelter were classified as primary contexts. Reorganization and re-deposition of skeletal segments were apparently ongoing and formed part of frequent maintenance procedures, conducted by the local Lacandon; or acts of vandalizing that have been ascribed to non-Lacandon travelers to the area. The overall preservation of the skeletal series was fairly good; however, due to exposition to weather conditions as well as other anthropogenic disturbing factors, many bones showed varying degrees of surface damage that in some cases limited systematic analysis of the skeletal segments.

Number and sex-and-age profiles of individuals. From the surface area, a total of twenty-two skulls, some with and others without mandible, were quantified. Six isolated mandibles could not be assigned to a skull, adding to the count $(\mathrm{MNI}=28)$. Most of these skeletal segments were recorded at the shrines of Mensabäk $(\mathrm{N}=9)$ and Sak Tat $(\mathrm{N}=15)$. The skulls belong mainly to young to middle aged adult individuals at the moment of death. The presence of 14 males and 11 female skulls parsimoniously indicates a balanced sex ratio of the overall series. The Sak Tat shrine demonstrates an equal deposition of males and females (5:5). Only the cranial series examined from the Mensabäk sanctuary is likely biased toward males $(7: 1)$.

The analysis of eight iliac bones (seven of which come from the Sak Tat shrine, table 1) indicate a balanced presence of males and females (4:4 ratio). Determination of age at death from the iliac bones suggests that five of seven adults examined died between age 30 and 50. Two individuals appear to have died after the age of 50 .

In addition to the skulls, sixty complete long bones could be analyzed. The majority $(\mathrm{N}=42)$ comes from the rock-shelter of Sak Tat, six more were analyzed at Mensabäk. The remainder were documented from the series of smaller crevices and shelters visited during the field season. As we can appreciate from table 2, the long bone most frequently documented in the shrines was the femur, with 11 left and 16 right segments, followed by twenty tibias $(\mathrm{N}=8$ left and $\mathrm{N}=12$ 


\begin{tabular}{|c|c|c|c|c|c|c|c|c|c|}
\hline \multirow{6}{*}{ 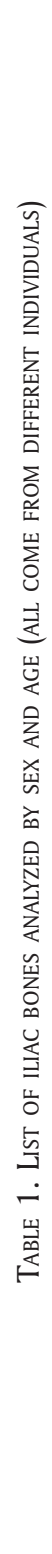 } & $\stackrel{㐅}{ٌ}$ & $\hat{\Sigma}$ & $\Sigma$ & Iિ & $\Sigma$ & I. & L & L & $\Sigma$ \\
\hline & 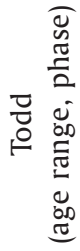 & & 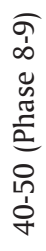 & 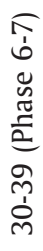 & & & & & \\
\hline & 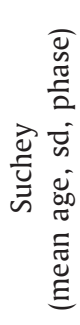 & 0 & 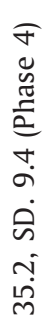 & 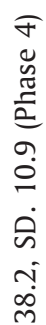 & & & & & \\
\hline & 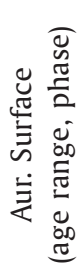 & $\begin{array}{l}\text { F } \\
\text { ç } \\
\text { के } \\
\text { bे }\end{array}$ & \begin{tabular}{l}
$\overparen{10}$ \\
\multirow{Z}{*}{} \\
$\dot{y}$
\end{tabular} & 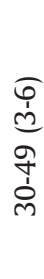 & $\begin{array}{l}\overparen{\infty} \\
0 \\
0 \\
1\end{array}$ & 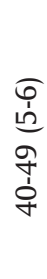 & 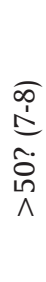 & & 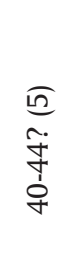 \\
\hline & 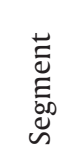 & 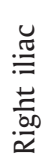 & 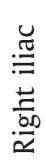 & 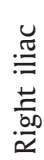 & 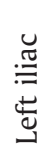 & 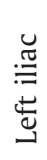 & 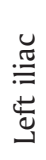 & 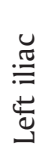 & 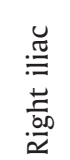 \\
\hline & $\stackrel{\mathscr{H}}{\sim}$ & 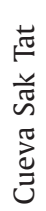 & 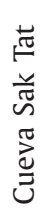 & 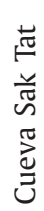 & 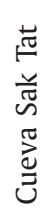 & 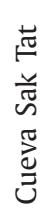 & 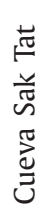 & 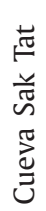 & 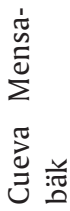 \\
\hline
\end{tabular}




\begin{tabular}{|c|c|c|c|}
\hline \multirow{13}{*}{$\begin{array}{l}\text { Sak Tat Shrine } \\
\qquad N=42\end{array}$} & \multirow{4}{*}{$\begin{array}{l}\text { Femur } \\
\mathrm{N}=15\end{array}$} & \multirow{2}{*}{ Right: 8} & Male: 7 \\
\hline & & & Female: 1 \\
\hline & & \multirow{2}{*}{ Left: 7} & Male: 4 \\
\hline & & & Female: 3 \\
\hline & \multirow{6}{*}{$\begin{array}{c}\text { Tibia } \\
\mathrm{N}=17\end{array}$} & \multirow{3}{*}{ Right: 11} & Male: 5 \\
\hline & & & Female: 4 \\
\hline & & & Not lateralized: 2 \\
\hline & & \multirow{3}{*}{ Left: 6} & Male: 4 \\
\hline & & & Female: 1 \\
\hline & & & Not lateralized:: 1 \\
\hline & \multirow{3}{*}{$\begin{array}{c}\text { Húmero } \\
\mathrm{N}=10\end{array}$} & \multirow{2}{*}{ Right: 6} & Male: 4 \\
\hline & & & Female: 2 \\
\hline & & Left: 4 & Male: 4 \\
\hline \multirow{6}{*}{$\begin{array}{c}\text { Mensabäk } \\
\text { Shrine } \\
N=6\end{array}$} & \multirow{3}{*}{$\begin{array}{c}\text { Femur } \\
\mathrm{N}=3\end{array}$} & Right: 1 & Female: 1 \\
\hline & & \multirow{2}{*}{ Left: 2} & Male: 1 \\
\hline & & & Female: 1 \\
\hline & Tibia & Right: 1 & Female: 1 \\
\hline & $\mathrm{N}=2$ & Left: 1 & Male: 1 \\
\hline & $\begin{array}{l}\text { Humerus } \\
\qquad \mathrm{N}=1\end{array}$ & Left: 1 & Male: 1 \\
\hline \multirow{5}{*}{$\begin{array}{l}\text { Chakah Tun Shrine } \\
\qquad N=7\end{array}$} & \multirow{3}{*}{$\begin{array}{c}\text { Femur } \\
\mathrm{N}=5\end{array}$} & \multirow{2}{*}{ Right: 4} & Male: 2 \\
\hline & & & Female: 2 \\
\hline & & Left: 1 & Female: 1 \\
\hline & \multirow{2}{*}{$\begin{array}{l}\text { Humerus } \\
\qquad \mathrm{N}=2\end{array}$} & \multirow{2}{*}{ Left: 2} & Male: 1 \\
\hline & & & Female: 1 \\
\hline \multirow{3}{*}{$\begin{array}{l}\text { Chucuch Na Shrine } \\
\qquad N=5\end{array}$} & \multirow{2}{*}{$\begin{array}{c}\text { Femur } \\
N=4\end{array}$} & Right: 3 & Female: 3 \\
\hline & & Left: 1 & Female: 1 \\
\hline & $\begin{array}{l}\text { Tibia } \\
N=1\end{array}$ & Left: 1 & Not lateralized: 1 \\
\hline
\end{tabular}

* One left and three right tibias could not be sexed. 
right) and 13 humeri ( $\mathrm{N}=7$ left and $\mathrm{N}=6$ right). In constrast to skulls and pelvises, whose sex ratio tends to equally represent both sexes, in the case of long bones, males tend to prevail over females with an approximate ratio of two to one, when sexed according to Wrobel et al. (2002).

Cultural body modification. Artificial cranial modification (head-shaping) was scored in 21 skulls (one more skull could not provide any information on whether or not it sported any modification). All vaults that were examined (100\%) presented artificial shaping, which in all cases corresponds to tabular erect forms, produced by placing the infant in a cradleboard (figure 5). With regard to the variants, 14 skulls presented the intermediate erect form, one skull presented a variant of the erect shape in the form of the lambdic plane, and two more skulls (both of the latter from the Mensabäk shrine) showed the parallelepiped or superior flattening. In four skulls the variant could not be determined. Lastly, one upper right canine from the Sak Tat shrine showed a distinct sulcus from artificial filing.

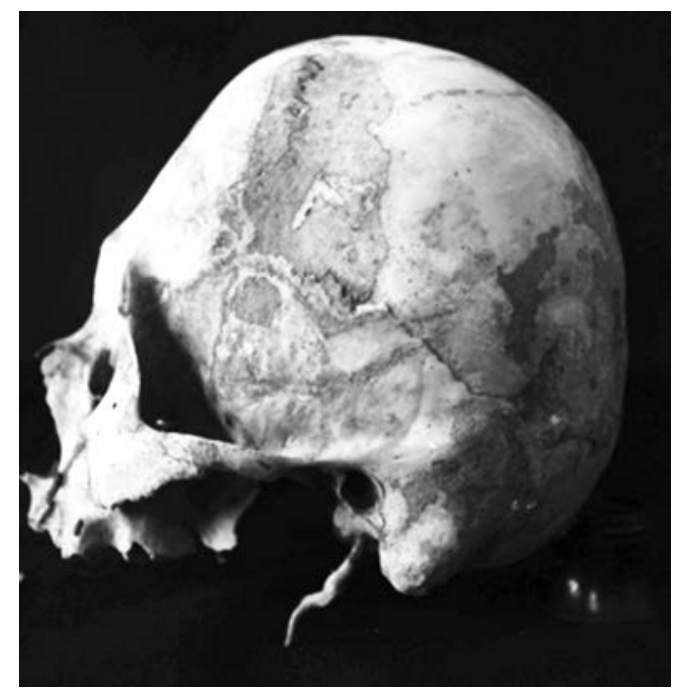

Figure 5. Skull in left lateral view, showing anteroposterior cultural flattening of the tabular erect type (Sak Tat rock-shelter)

Appearance and living conditions. Stature estimated from the maximum femoral length (Del Ángel and Cisneros, 2004) suggests an average of $156.82 \mathrm{~cm}$ in males $(+/-4.7 ; \mathrm{N}=7)$, while the maximum tibial lengths without the intercondylar eminence provide a mean of $160.29(+/-3.5 ; \mathrm{N}=5)$. Female stature estimates range between $145.59-149.47$ for the femur $(\mathrm{N}=3)$ and $143.97-148.33 \mathrm{~cm}$ for the tibia $(\mathrm{N}=3)$. Calculated values appear to be reduced in males and females when compared with those estimated for pre-Hispanic populations (Márquez and Del Ángel, 1997; Tiesler, 1999). 
Regarding robusticity, muscular insertions and origins appear above average in the limb bones of individuals of both sexes, which indicates a demanding physical regime and intense mobility. In fact, the pilastric indexes, which measure the cross-sectional properties of mid-shaft femurs, average 103 in males and 117.8 in females. They are equal to, or more marked than, the ones calculated for pre-Hispanic times (Tiesler, 1999). Their meric indexes average 80 (platimeric), which has been identified by some authors with increased mobility, coupled with undernutrition (Capasso et al., 1999). However, given that robusticity is a variable employed for sexing the long bones, based on Wrobel et al. (2002) discriminant function, the difference between sexes must be treated with caution.

General patterns of pathological conditions were assessed through the analysis of several indicators of metabolic, carential, localized or systemic infectious conditions and traumas. Combined indicators show that 8 out of $14(57.1 \%)$ individual skulls had suffered from chronic nutritional stress, as evidenced by the presence of porotic hyperostosis, due to lack of vitamin C or D (Schultz, 2001), megaloblastic anemia (Walker et al., 2009) as well as infection during infancy (figure 6). It must be noted that vitamin D deficiency should also be detected in long bones, and none of these segments presented such manifestations. However, given the secondary nature of these deposits, we lack analytical methods to assign the long bones to the skull of each individual, and it is also likely that the long bones belonging to the eight skulls with porotic hyperostosis do not form part of our sample. We add that cribra orbitalia, which appears as a trabecularization of the orbital roof, was diagnosed only in 2 out of 15 skulls (13.3\%), despite an etiology that is similar (though not identical) to the one that characterizes porotic hyperostosis (Ortner, 2003).

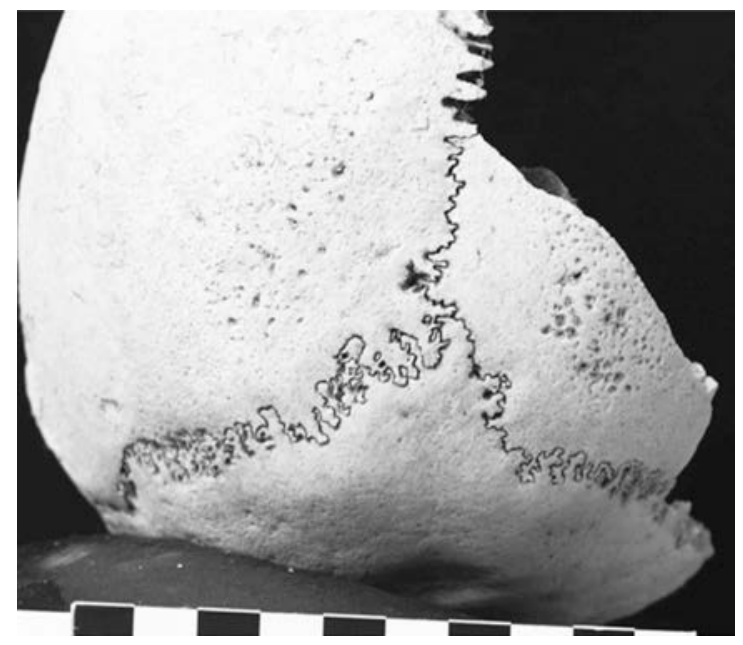

FIGURE 6. Spongy hyperostosis of both parietal bones of the cranial vault (Sak Tat rock-shelter) 
Periostal reactions, which were recorded in the long bones of the lower extremities, were recorded in six specimens out of $16(37.5 \%)$. Such reactions were not localized in small areas of the long bones, which may support the idea that they had been caused by systemic ailments instead of local traumatic injuries. Notwithstanding, the possibility must be entertained that a diagnostic marker of such conditions is represented by the skeletal distribution of the pathological evidence like bilaterality, extension to contiguous bony segments, distribution in the upper vs. lower limbs, and so forth; unfortunately, due to the secondary state of the remains, such approximation could not be pursued here.

Skeletal markers of violence and trauma inflicted in life have a different motivation and signature from that of posthumous manipulation. At the Sak Tat shrine, one skull presented a series of thin cut-marks on the frontal bone (figure 7). They crossed the upper frontal bone transversally some 10 to $25 \mathrm{~mm}$. They were likely produced with a metal tool, considering the clean, narrow, v-shaped profiles of the marks, which can easily be appreciated even without a microscope and which differ from the more rounded grooves produced by chert or obsidian tools (Tiesler and Oliva, 2010). The morphology and chromatic appearance indicate that they had been executed in ancient times and were not the result of recent accidental taphonomic interventions. Rather, they indicate a repetitive slicing action in contrast with an impact, which could have stemmed from scalping. Such a practice was established among the ancient Maya for ritual purposes and/or as part of war-trophy taking, and has been reported also for colonial times (Fitzsimmons, 2009, 2011; Nájera, 1987; Tiesler, 2007).

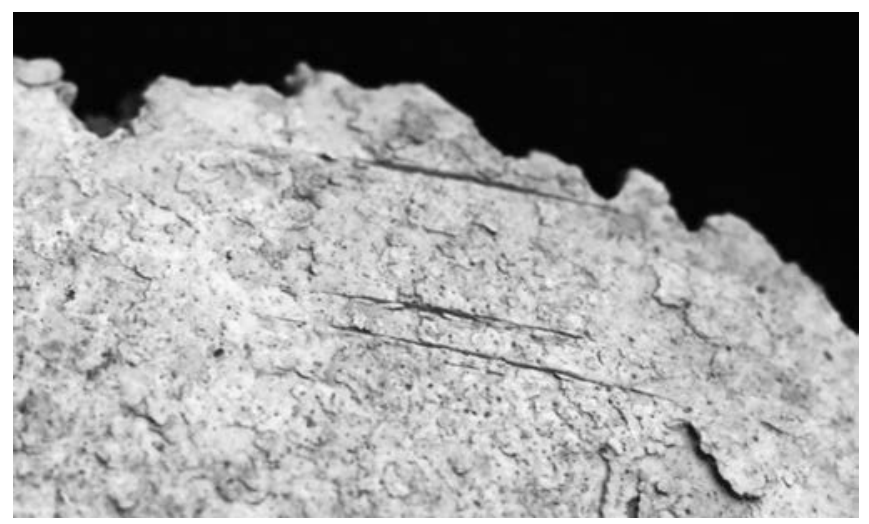

FIGURE 7. Parallel slicing marks on the frontal bone (Sak Tat rock-shelter)

While these cut-marks were effected after the individual had already perished, others stem from the time surrounding death. One violent chop of one adult mandible removed the left posterior angle (gonion) from the vertical ramus (figure 8). Such an impact was likely carried out with a machete, which has been a 
commonly used working and defensive tool since colonial times. Unfortunately, no skeletal segments remain that allow assessment of the impact's directionality. One right tibia at the shrine exhibits a fracture also apparently caused by a machete blow, or perhaps self-inflicted. One other skull from Sak Tat exhibited an unhealed blunt force trauma, which fractured the cranial vault. The lack of any defined mark of impact suggests that the action was not perpetrated with any weapon, and we cautiously believe that the person might have fallen from a high altitude, thereby crushing the head on the ground (figure 9). Lastly, a healed midshaft fracture of an adult femur also received our attention in the Sak Tat series (figure 10). The diaphysis had remained almost straight during the healing process, which suggests that the person had received some sort of medical attention in the form of stabilization and splinting of the leg, a measure more common in post-contact times than before the conquest.

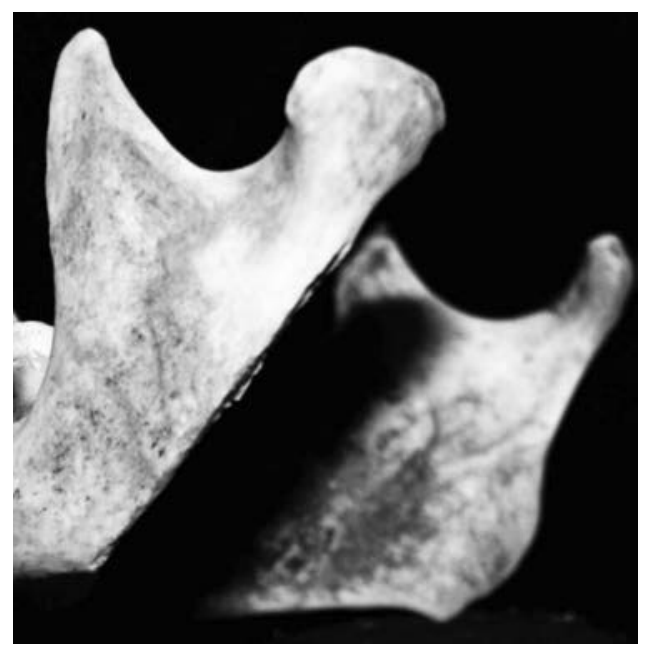

FiguRE 8. Unhealed chop mark of an adult mandible (Sak Tat rock-shelter)

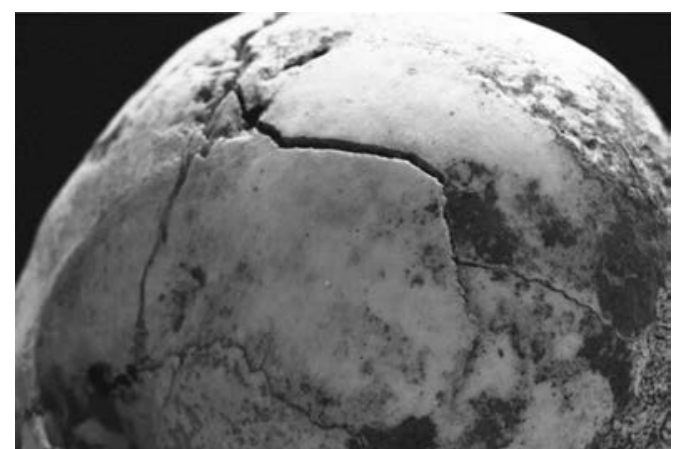

FiguRE 9. Blunt force trauma in the skull vault of an adult individual (Sak Tat rock-shelter) 


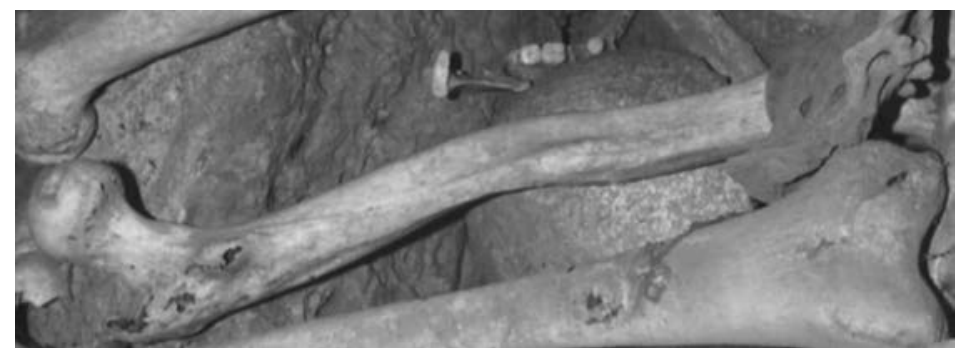

FIGURE 10. Healed mid-shaft fracture of a left adult femur with signs of medical stabilization (Sak Tat rock-shelter)

\section{Discussion}

The joint data elaboration from the shrines allows for a number of generalizations of the human surface assemblages from the sacred shrines around the Mensabäk lagoon. The taphonomic evidence indicates that segments of some thirty or more adults of both sexes ended up on the surface of distinctive rock shrines around the shores of the Mensabäk lake. Nearly all of the remains are of a secondary nature (with the exception of two mummified bodies that had been laid down in a stone cleft high above the ground which was difficult to access). As for the remainder, it follows that skeletal segments must have been re-deposited on the ground of the shelter after exhumation or have been introduced from far-off places of primary interment. As expected, and as occurs in bundle burials when skeletons from primary depositions are recovered and returned to their place of origins, skulls, pelvic wings, and long bones are usually those most commonly selected, leaving behind remnants (primary reductions) of more brittle, smaller and/ or less representative bones like hands and feet, ribs and vertebras. Also among the pre-Hispanic Maya, skulls and long bones appear to have been the preferred segments to be intentionally removed from their primary deposition space to undergo protracted mortuary treatments (Fitzsimmons, 2011; Tiesler, 2007).

From a collective perspective, age estimations indicate the prevalence of adult individuals, equally represented by males and females, at least in the overall count. The exception seems to be the profile from the Mensabäk shrine, with a predominance of male segments. The adult age categories more frequently encountered are between 30 and 50 years of age, as suggested from the skull, and slightly older when age is estimated from the pelvis. Conversely, no infants or juvenile remains were counted among the segments that were systematically analyzed. Such an age distribution does not reflect a "normal" demographic profile and therefore is not representative of the population's mortality pattern (Paine and Boldsen, 2002; Tiesler et al., 2005). Neither does the observed age profile stem from mortal epidemic cycles (Paine and Boldsen, 2002), whose age distribution tends to be balanced between all the age classes. Typically, anthropological studies consider a demographic curve heavily biased towards young and mature 
adults (with a net underrepresentation of subadults and elderly individuals) as a byproduct of either selective burial practices and/or bone deterioration that tends to destroy more fragile bones like those of infants and of the elderly (Hoppa and Waupel, 2002; Milner et al., 2000).

Given the secondary nature of the bony assemblages, the skewed distribution can be considered in all likelihood as the product of a culturally introduced bias. In fact, skeletal remains did not selectively preserve in relation to their own intrinsic robustness and strength; they were deposited in accordance with ritual and cultural beliefs. According to local tradition, the individuals who could stand before the gods in the sacred places are considered the "caretakers of the gods"; similarly, the remains that were intentionally redistributed within the sacred shrines can correspond to ritual beliefs linked to the cult of the ancestors (Fitzsimmons, 2011; Weiss-Krejci, 2006). It seems evident that children, juveniles and subadults did not meet the necessary requirement to achieve such status in the community. The fact that few elderly individuals were encountered could be linked to a general good preservation of the skeletal remains, in particular the skulls. On the other hand, with regard to the pelvis, at least two individuals were 50 years of age or older. It must be stressed that normal macroscopic indicators of age at death provide reliable estimates until age 40; after that age, population variability becomes a limiting factor for an accurate estimate of the demographic profile. This methodological limitation, alongside a potential culturally-induced under-representation of elderly people, might explain the paucity of individuals older than 50; if this were not the case, then it could underscore low life expectancy among the Postclassic and post-contact Maya dwellers of the Mensabäk area.

Intentional modification of the cranial vault (head shaping) represented a very peculiar tradition among the ancient Mayas, which was practiced by women on the newborn infants, who would carry such visual emblem for the rest of his/her life. It formed part of the Maya cultural repertoire for at least three millennia. Previous studies (Tiesler, 1998, 1999, 2012) indicate that more than $80 \%$ of the pre-Hispanic skulls in the Maya realm sported such form of body modification. Tiesler (2012) notes that during the Classic Period, intentional modification of the skull generated a large array of shapes and styles, obtained in compression cradleboards or directly shaped between head boards, adjusted to the skull of the infant. After the onset of the second millennium A.D., techniques and therefore artificial head shapes gained in uniformity, with tabular erect shapes ever more prevalent in the skeletal record. These were achieved by placing the baby in compression cradleboards.

Eventually, the Spanish conquest would force the abandonment of such practices, initially in the urban population and then, slowly, also in the rural hinterlands (Tiesler and Zabala, 2011). Among the Lacandon Maya, the isolation from European oppression appears to have led to the persistence of this practice until recent times (Palka, 2005). Even during the late $19^{\text {th }}$ century, Maudslay notes flattened foreheads among the elderly Lacandon and points out that the custom 
of head modeling was slowly being abandoned. "The extremely sloping forehead [of elder Lacandon males] was not quite so noticeable in the younger men, and it may be that the custom of binding back the forehead in infancy, which undoubtedly obtained amongst the ancients, is being now abandoned" (Maudslay and Maudslay, 1899: 236-237).

Given the high prevalence of tabular erect shapes found at the Mensabäk shrines, it is likely that these skulls date to Postclassic or to colonial times. Moreover, the presence of the parallelepiped variant recorded in two crania at the Mensabäk shrine suggests potential earlier dates, in light of the fact that this variant, which is characterized by a strong superior flattening of the cranial vault apart from the antero-posterior planes, reached its climax in the Maya area much earlier, during the last centuries of the first millennium A.D. and the onset of the second millennium (Tiesler, 2012).

The estimated stature determined from the length of the long bones seems to be shorter in males in comparison with their pre-Hispanic counterparts. Márquez and Del Ángel (1997) and Tiesler (2001) have evaluated female and male average statures of a large array of samples around the Yucatán peninsula, the Peten and in the Maya highlands and conclude that males reached a stature approximating $160 \mathrm{~cm}$, while female statures oscillated more but averaged 145 to $150 \mathrm{~cm}$ (see also Haviland, 1967; Sierra et al., 2014). Although no inter-site differences are reported (the authors gathered all the specimens together), Tiesler demonstrates a decrease in stature towards the Postclassic, especially in females. This trend should have continued after contact as well, as the low average values encountered in the shrines at Mensabäk suggest, in particular for the male segment of the population.

The reduced stature around the Mensabäk lagoon does not seem to have preferentially affected one sex over the other. In comparison with Xcambó, for example, both sexes average about six centimeters less, while the comparison with Tikal (Haviland, 1967) shows similar results for both males and females. Although we cannot rule out genetic factors behind such reduced values, it seems plausible to infer that stressful conditions (undernutrition combined with pathological loads) may have come to limit the growth potentials in this population.

As regards porotic hyperostosis and cribra orbitalia, they are frequently detected in archaeological specimens; they are more often evident in an active state in subadults rather than in adults (Ortner, 2003; Stuart-Macadam, 1985; Schultz, 2001). Although both conditions have been associated in the literature with anemic conditions (El-Najjar et al., 1976; Larsen, 1997; Stuart-Macadam, 1987, 1989), and are sometimes conflated under the term porotic hyperostosis, paleopathological and clinical evidence suggests they often have divergent etiologies (Walker et al., 2009). Neither of the two directly expresses any specific pathological conditions (a disease) (Grauer, 2008), but rather identifies morphological features with a complex origin (Schultz, 2001). In order to diagnose reliably the specific etiology of such skeletal manifestations, Schultz (2001) recommends histomor- 
phological inspection of the pathological manifestation. Although we are aware that such a step is important for a correct diagnosis, the data collection in the field at the sacred shrines has not included sampling for further analyses thus far, which limits proper understanding of the conditions that generated the porotic manifestations.

By itself, the high frequency of porotic lesions in the cranial vault encountered in this study (57.1\%) is indicative of considerable loads of non-specific stressful conditions. In fact, it is much higher than the frequencies recorded respectively in other, large Maya series. For example, the Classic period series from coastal Xcambó presents hyperostosis in only $22.45 \%$ of the skulls and in $19.5 \%$ of the eye vaults of (Sierra et al., 2014), which has been interpreted as signs of overall good health. Similarly, very few cases were reported at Caracol and at Santa Rita Corozal (Chase, 1997) and no porotic hyperostosis was detected at Tayasal (Chase, 1997). In a similar fashion, Saul and Saul (1997) described only two cases of porosity in the cranial vault out of 49 skulls analyzed at Cuello. Unfortunately, the paucity of dental pieces in our series translates into a lack of information on linear enamel hypoplasia, another non-specific indicator of physiological stress, which does not permit more thorough inferences on living conditions experienced during the individuals' subadult life at Mensabäk.

Periostal reactions are postcranial conditions that are difficult to interpret in secondary remains. The fact that $37.55 \%$ of the skeletal segments of the lower limbs present periostal apposition may be indicative of a large array of causative factors that range from scurvy, localized traumas, systemic infections and more (Ortner, 2003), but the impossibility of assessing the patterns of distribution in the skeleton more systematically hampers any real understanding of the reasons behind such pathological conditions.

Lastly, the presence of traumatic injuries and manifestations of pre- and peri mortem cultural intervention indicate hazardous living conditions (Cucina and Tiesler, 2014). One frontal bone shows posthumous processing, while one mandible presented evidence of intentional peri mortem violence. In both cases, we identified sharp metal objects as instruments, thereby suggesting a post-contact date. Unfortunately, the isolated nature of the segments hampers any broader understanding of the direction of the impacts or the circumstances that led to them. Certainly, the total absence of any evidence of remodeling and healing in the mandible indicates that death occurred immediately, or within a very short time after the impact. Other healed or unhealed lesions, like one perimortem cranial blunt force trauma and a medically stabilized midshaft fracture of an adult femur, were more likely the product of accidents and in the latter case suggest medical attention of some sort. 


\section{Conclusions}

The human skeletal assemblages from the sacred shelters' surface, with some few exceptions, belong to secondary interments, which we have argued accrued over a long period during the second millennium $\mathrm{AD}$. This new information is consistent with the interpretation by Boremansen and Blom, who believe these to have been extracted from the looted cave grounds (Boremanse, 1993; Petryshyn, 2005).

Where did the mortal remains of those individuals, whom the local tradition still identify with the "caretakers of the Gods," come from? Answers to this and other, related questions probably lie beneath the surface of the sanctuary under study. Maybe the dead had been buried there, their segments to be removed and exposed gradually over the centuries, to be extracted from the ground and venerated by distant descent groups up to the present. Interestingly, and contrary to what we might expect, given the modern androcentric rhetoric on these human remains, those who in life were women perform equal caretaking functions as the males, an aspect that also speaks in favor of more general original uses of the shrines as mortuary repositories. Naturally, the lack of children among the cohort also leaves questions open in regard to selection criteria.

A further aspect concerns group identity and provenience. At present, the lack of isotopic information renders speculative any attempt at assessing the place of origin of the individuals whose remains formed part of the shrines. The recent dating of only two samples from Sak Tat allows us to start placing the shrines into chronological context; however, further information will be necessary to understand their overall evolution as sacred places of worship and ritual activity areas. It is important to underscore that the skeletal assemblages have been and continue being handled and reorganized during ceremonies (although ritual uses have dramatically diminished during the last few generations), as part of regular maintenance processes, and as consequence of acts of vandalism perpetrated by rival non-Lacandon communities, as described in detail elsewhere (Cucina and Tiesler, 2014).

Lastly, the information gathered from the sacred shrines around the Mensabäk lagoon also confirms the analytical potentials of this sort of study for approximating the living conditions of the past in this cultural area. The direct dates and artifactual associations (head shapes, ceramic wares, metal uses, etc.) tie in with the physical indications of living conditions to suggest harsh, physically demanding life styles, violence, a deficient nutritional regimen, and continuity with pre-Hispanic infant cradling, dental decoration, and ritual body treatments. Unfortunately, the relative paucity of the sample, the lack of a precise chronological dating, and the secondary organization of the bones, serves to limit the possibilities of expanding the information towards a population interpretation at the present time.

Information from contemporary Lacandon Maya at Mensabäk sheds additional light on the uses and meanings of the Mensabäk shrines. As pointed out above, 
the local Lacandons believe that the caves and rock-shelters that are nested in the tall cliffs at the lake are homes of the gods (Boremanse, 1998; McGee, 1990). There is a distinct feeling among the community members that the bones are the mortal remains of gods or humans that were left as they passed into the homes of the gods. It is vaguely recalled that, in the olden times, men transferred skulls and bones at the shrines from ancient burials. Likewise, used or "dead" incense burners have been left at the shrines, where ceremonies have been held to help cure sick relatives and obtain abundant harvests.

In the case of the Mensabäk shrine, Lacandon people feel at present that the dead enter the cliff house of Mensabäk where they stay to assist this god at the edge of the lake. Interestingly, Mensabäk is the name of the main god of rain for the Lacandon Maya. His home is thus linked to the ancestral notion of the Tlalocan of Postclassic central Mexico where the souls of the dead were believed to dwell in a watery paradise (López Austin, 1997). The association of the Mensabäk shrine as Tlalocan is confirmed by a nearby rock painting on the cliff itself, which depicts Tlaloc releasing rain drops (Palka and Sánchez, n. d.). The placement of human bones at this shrine and others in the region therefore acquires a new sense: by returning the ancestors to the homes of the gods, they could see to the needs of the living, such as rain, good health, and bountiful milpas.

Future investigations at Mensabäk will further help clarify the chronology and functions of the human bone shrines in this area and beyond. Additional excavations and surveys of caves, rock-shelters, and sites around the lagoon will surely provide insights regarding demographic profiles, lifeways, ritual, and health in a Maya population dating from Postclassic to historic times. Collaborations with Lacandon Maya informants will also continue to lend important ethnographic input for understanding present and past Maya culture at Mensabäk. In this regard, we also hope that past, poorly understood burial patterns in Maya civilization will be illuminated by this project.

Acknowledgements. Our grateful recognition goes to our colleagues Gabrielle Vail and to Marianne Gabriel for their initiative to organize a timely panel on Maya ritual behavior that inspired this contribution, as well as for their continuous support during the editorial process. The authors collected the information referenced as part of the collaborative research between the Universidad Autónoma de Yucatán and the University of Illinois in Chicago (Mensabäk Archaeological. Project). Here we wish to thank Julio Chi Keb and Shintaro Suzuki, who accompanied us during the reconnaissance fieldwork conducted in 2010. We are also indebted to other senior project personnel, specifically Adriana Fabiola Sánchez Balderas, and the Lacandon community members of Mensabäk for kindly sharing with us their views of life, their knowledge of the old ways, their humor and their infinite curiosity. 


\section{REFERENCES}

Adams, Bradley J. and Lyle Konigsberg

2008 "How Many People? Determining the number of individuals represented by commingled human remains", Recovery, analysis, and identification of commingled human remains, pp. 241-255, B. Adams and J. Byrd (eds.). Totowa: Humana Press.

Bassie-Sweet, Karen

1996 At the Edge of the World. Caves and Late Classic Maya World View. Oklahoma: University of Oklahoma Press.

Blom, Frans

1954 "Ossuaries, Cremation, and Secondary Burials Among the Maya of Chiapas, México”, Journal de la Société des Américanistes, XLIII: 123-135.

Bonor Villarejo, Juan L.

1989 Las cuevas mayas: simbolismo y ritual. Madrid: Universidad Complutense, Instituto de Cooperación Iberoamericana.

Boremanse, Didier

1993 "The Faith of the Real People: The Lacandon of the Chiapas Rain Forest", South and Meso-American Native Spirituality: From the Cult of the Feathered Serpent to the Theology of Liberation, pp. 324-351, G. H. Gossen (ed.). New York: The Crossroad Publishing Company.

1998 Hach Winik. The Lacandon Maya of Chiapas, Southern Mexico. Albany: University of Albany, Institute for Mesoamerican Studies.

Brady, James and Keith M. Prufer (eds.)

2005 In the Maw of the Earth Monster: Studies of Mesoamerican Ritual Cave Use (Linda Schele Series in Maya and Pre-Columbian Studies). Austin: University of Texas.

Bruzek, Jaroslav

2002 "A Method for Visual Determination of Sex Using the Human Hip Bone", American Journal of Physical Anthropology, 117: 157-168.

Buikstra, Jane and Douglas Ubelaker

1994 Standards for Data Collection from Human Skeletal Remains. Tuscaloosa: Arkansas Archaeological Survey Research (Series, 44).

Capasso, Luigi, Kenneth A. R. Kennedy and Cynthia A. Wilczak

1999 Atlas of Occupational Markers on Human Remains. Teramo: Edigrafitalg.

Cucina, Andrea and Vera Tiesler

In press "Mortuary Pathways and Ritual Meanings Related to Maya Human Bone Deposits in Caves and Cenotes", The Bioarchaeology of Space and Place: Ideology and Meaning in Maya Mortuary Contexts, G. D. Wrobel (ed.). New York: Springer. 
Chase, Diane Z.

1997 "Southern Lowland Maya Archaeology and Human Skeletal Remains: Intepretations from Caracol (Belize), Santa Rita Corozal (Belize) and Tayasal (Guatemala)", Bones of the Maya, pp. 15-27, S. L. Whittington and D. M. Reed (eds.). Washington D. C.: Smithsonian Institution Press.

Del Ángel, Andrés and Héctor B. Cisneros

2004 "Technical note: Modification of Regression Equation Used to Estimate Stature in Mesoamerican Skeletal Remains", American Journal of Physical Anthropology, 125 (3): 264-265.

Dembo, Adolfo and José Imbelloni

1938 Deformaciones intencionales del cuerpo humano de carácter étnico. Buenos Aires: Biblioteca Humanior.

Duday, Henri

2009 The Archaeology of the Dead. Lectures in Archaeothanatology. Oxford: Oxbow Books.

El-Najjar, Mahamoud Y., Dennis J. Ryan, Christy G. Turner II and Betsy Lozoff.

1976 "The Etiology of Porotic Hyperostosis Among the Prehistoric and Historic Anasazi Indians of Southwestern United States", American Journal of Physical Anthropology, 44: 477-487.

Ferembach, Denise, Ilde Schwidetzky and M. Stloukal

1980 "Recommendations for Age and Sex Diagnoses of Skeletons", Journal of Human Evolution, 9: 517-549.

Fitzsimmons, James L.

2009 Death and the Classic Maya Kings. Austin: University of Texas Press.

2011 "Perspectives on Death and Transformation in Ancient Maya Society: Human Remains as a Means to an End", Living with the Dead. Mortuary Ritual in Mesoamerica, pp. 53-77, J. L. Fitzsimmons and I. Shimada (eds.). Tucson: The University of Arizona Press.

Grauer, Anne L.

2008 "Macroscopic Analysis and Data Collection in Paleopathology", Advances in Human Paleopathology, pp. 57-76, R. Pinhasi and S. Mays (eds.). Chichester: Wiley.

Haviland, William

1967 "Stature at Tikal: Implications for Ancient Maya Demography and Social Organization”, American Antiquity, 32: 316-325.

Hoppa, Robert D. and James W. Waupel (eds.)

2002 Paleodemography. Age Distribution from Skeletal Samples. Cambridge: Cambridge University Press. 
Larsen, Clark S.

1997 Bioarchaeology. Interpreting Behavior from the Human Skeleton. Cambridge: Cambridge University Press.

López Austin, Alfredo

1997 Tamoanchan, Tlalocan: Places of Mist. Boulder: University Press of Colorado.

Lovejoy, C. Owen, Richard S. Meindl, Thomas R. Pryzbeck and Robert P. Mensforth

1985 "Chronological Metamorphosis of the Auricular Surface of the Ilium: a New Method for the Detemination of Adult Skeletal Age at Death", American Journal of Physical Anthropology, 68: 15-28.

Márquez Morfín, Lourdes and Andrés del Ángel

1997 "Height Among Prehispanic Maya of the Yucatán Peninsula: A Reconsideration", Bones of the Maya, pp. 51-61, S. L. Whittington and D. M. Reed (eds.). Washington D. C.: Smithsonian Institution Press.

Maudslay, Anne and Alfred P. Maudslay

1899 A Glimpe at Guatemala, and Some Notes on the Ancient Monuments of Central America. London: John Murray.

McGee, R. Jon

1990 Life, Ritual and Religion Among the Lacandon Maya. Belmont: Wadsworth Publishing.

Milner George R., James W. Wood and Jesper L. Boldsen

2000 "Paleodemography", Biological Anthropology of the Human Skeleton, pp. 467498, M. A. Katzenberg and S. H. Saunders (eds.). New York: Wiley Liss.

Nájera Coronado, Martha Ilia

1987 El don de la sangre en el equilibrio cósmico. Mexico: Universidad Nacional Autónoma de México, Instituto de Investigaciones Filológicas, Centro de Estudios Mayas.

Ortner, Donald J.

2003 Identification of Pathological. Conditions in Human Skeletal Remains, $2^{\text {nd }}$ ed. Amsterdam: Academic Press.

Palka, Joel W.

2005 Unconquered Lacandon Maya. Ethnohistory and Archaeology of Indigenous Culture Change. Gainesville: University Press of Florida.

Palka, Joel W. and A. Fabiola Sánchez Balderas

n. d. "Sitios sagrados de los mayas posclásicos e históricos en Mensabäk, Selva Lacandona, Chiapas, México", Arqueología reciente en Chiapas, M. Pye and L. Lowe (eds.). Provo: Brigham Young University (Papers of the New World Archaeological Foundation, 72). 
Paine, Robert R. and Jesper L. Boldsen

2002 "Linking Age-at-death Distributions and Ancient Population Dynamics: A Case Study”, Paleodemography. Age Distribution from Skeletal Samples, pp. 169-180, R. D. Hoppa and J. W. Vaupel (eds.). Cambridge: Cambridge University Press.

Petryshyn, Jaroslaw Theodore

2005 "A Lacandon Religious Ritual in the Cave of the God Tsibaná at the Holy Lake of Mensabok in the Rainforest of Chiapas", In the Maw of the Earth Monster: Studies of Mesoamerican Ritual Cave Use, pp. 328-341, J. Brady and K. M. Prufer (eds.). Austin: University of Texas (Linda Schele Series in Maya and Pre-Columbian Studies).

Romano Pacheco, Arturo

1965 Estudio morfológico de la deformación craneana en Tamuín, S.L.P. y en la Isla del Ídolo, Veracruz. México: Instituto Nacional de Antropología e Historia (Serie de Investigaciones, 10).

Sánchez-Mejorada, Gabriela et al.

2011 "Valoración del método de diagnóstico sexual probabilístico (DSP) en una colección osteológica mexicana”, Estudios de Antropología Biológica, XV: 359-374.

Saul, Julie M. and Frank P. Saul

1997 "The Preclassic Skeletons from Cuello", Bones of the Maya, pp. 28-50, S. L. Whittington and D. M. Reed (eds.). Washington, D. C.: Smithsonian Institution Press.

Scott, Ann M. and James E. Brady

2005 "Human Remains in Lowland Maya Caves", The Maw of the Earth Monster: Studies of Mesoamerican Ritual Cave Use, pp. 263-284, K. M. Prufer and J. Brady (eds.). Austin: University of Texas (Linda Schele Series in Maya and Pre-Columbian Studies).

Schultz, Michael

2001 "Paleohistopathology of Bone: A New Approach to the Study of Ancient Diseases", Yearbook of Physical Anthropology, 44: 106-147.

Sierra Sosa, Thelma et al.

In press "Vida y muerte en el puerto de Xcambó, Yucatán: datos arqueológicos, mortuorios y poblacionales", British Archaeological Reports. Oxford: Archaeopress.

Steele, Gentry and Claude A. Bramblet

1988 The Anatomy and Biology of the Human Skeleton. Austin: Texas University Press.

Stone, Andrea J.

1995 Images from the Underworld. Naj Tunich and the Tradition of Maya Cave Painting. Austin: University of Texas Press. 
Stuart-Macadam, Patricia

1985 "Porotic Hyperostosis: Representative of a Childhood Condition", American Journal of Physical Anthropology, 66: 391-398.

1987 "Porotic Hyperostosis: New Evidence to Support the Anemia Theory", American Journal of Physical Anthropology, 74: 521-526.

1989 "Porotic Hyperostosis: Relationship Between Orbital and Vault lesions", American Journal of Physical Anthropology, 80: 187-193.

Tiesler, Vera

1999 "Rasgos bioculturales entre los antiguos mayas: aspectos arqueológicos y sociales", PhD Dissertation in Anthropology. México: Universidad Nacional Autónoma de México.

2001 "La estatura entre los mayas prehispánicos. Consideraciones bioculturales", Estudios de Antropología Biológica, X: 257-273.

2005 "What Can the Bones Really Tell Us? The Study of Human Skeletal Remains from Cenotes", Stone Houses and Earth Lords. Maya Religion in the Cave Context, pp. 341-363, K. M. Prufer and J. E. Brady (eds.). Boulder: University of Colorado Press.

2007 "Funerary or Nonfunerary? New References in Identifying Ancient Maya Sacrificial and Postsacrificial Behaviors from Human Assemblages", New Perspectives on Human Sacrifice and Ritual. Body Treatments in Ancient Maya Society, pp. 14-45, V. Tiesler and A. Cucina (eds.). New York: Springer.

2012 Transformarse en maya. El modelado cefálico entre los mayas prehispánicos y coloniales. México: Universidad Nacional Autónoma de México y Universidad Autónoma de Yucatán.

2012 The Bioarchaeology of Artificial Cranial Modifications. New Approaches to Head Shaping and its Meanings in Pre-Columbian Mesoamerica and Beyond. New York: Springer Press.

Tiesler, Vera and Andrea Cucina

2012 "Where are the Warriors? Cranial Trauma Patterns and Conflict Among the Ancient Maya”, The Bioarchaeology of Violence, pp. 160-179, D. L. Martin, R. P. Harrod and V. R. Pérez (eds.). Gainesville: University Press of Florida.

Tiesler, Vera and Ivan Oliva

2010 "Identity, Alienation and Integration: Body Modifications in the Early Colonial Population from Campeche", Natives, Europeans and Africans in Colonial. Campeche. History and Archaeology, pp. 130-151, V. Tiesler, P. Zabala and A. Cucina (eds.). Gainesville: Florida University Press.

Tiesler, Vera and Pilar Zabala Aguirre

2011 "El modelado artificial de la cabeza durante la Colonia. Una tradición maya en el espejo de las fuentes históricas”, Estudios de Cultura Maya, 38: 75-96.

Tiesler, Vera et al.

2005 "Comercio, dinámicas biosociales y estructura poblacional del asentamiento costero de Xcambó, Yucatán”, Los investigadores de la cultura maya, 13, pp. 365372. Campeche: Universidad Autónoma de Campeche. 
Walker, Philip L. et al.

2009 "The cause of Porotic Hyperostosis and Cribra Orbitalis: A Reappraisal of the Iron-deficiency Hypothesis", American Journal of Physical Anthropology, 139: 109-125.

Weiss-Krejci, Estella

2006 "The Maya Corpse: Body Processing from Preclassic to Postclassic Times in the Maya Highlands and Lowlands", Jaws of the Underworld. Life, Death, and Rebirth Among the Ancient Maya, pp. 71-86, P. Colas, G. LeFort and B. Liljefors Tersson (eds.). Markt Schwaben: Anton Saurwein (Acta Mesoamericana, 16).

Wrobel, Gabriel D., Marie E. Danforth and Carl Armstrong

2002 "Estimating Sex of Maya Skeletons by Discriminant Function Analysis of Long Bone Measurements from the Protohistoric Maya Site of Tipu, Belize", Ancient Mesoamerica, 13: 255-263. 
